Open Access

\title{
Importance of Guanxi in Chinese apparel new venture success: a mixed-method approach
}

\author{
Li Zhao* (1) and Jung Ha-Brookshire
}

\author{
* Correspondence: zhaol1@missouri. \\ edu \\ University of Missouri, 137 Stanley \\ Hall, Columbia, MO 65211, USA
}

\begin{abstract}
The significant role of new ventures in economic and social development has led practitioners and researchers to search for the factors that affect new venture performance. In the Chinese apparel industry context, relationship ("guanxi") as a central idea in Chinese society deeply influences all kinds of business. High quality relationships with supply chain partners, as a key resource, would help new ventures create competitive advantages and, hence, influence new venture performance. This study was designed to investigate the link between firms' network relationships and new venture performance in the Chinese apparel industry. Using the resource-based view (Journal of Management 17:99-120, 1991) and social network theory (Administrative Science Quarterly 45:425-455, 2001), this study offers a mixedmethods exploratory approach to understanding the importance of guanxi in Chinese apparel new venture success. Results showed that three dimensions of new venture network relationship quality have positive impacts on the new ventures' performance. This finding is consistent with social network theory and revealed that competitive advantage may be achieved through social network resources. In particular, for Chinese apparel new ventures, guanxi is an important resource for sustained competitive advantage among established businesses in China.
\end{abstract}

Keywords: New ventures, Guanxi, Success, Apparel industry

\section{Background}

The Chinese apparel industry has been in a growth phase since the late 1970s, when the government launched an economic open-door policy. In recent years, the sector has developed at an accelerating speed and is now a significant pillar in the apparel industry worldwide (Li, 2014). Numerous new ventures emerged during this period of growth. Meng (2013) points out that new ventures play a key role in Chinese economic development. They are a driving force for innovation and increased employment opportunities. Today, two-thirds of apparel output in the Chinese apparel industry is produced by small- and medium-sized enterprises (SMEs). Most of these SMEs in the Chinese apparel industry are new ventures, playing an important role in both promoting economic development and maintaining social order by reducing unemployment (Li, 2014). However, it has been a huge challenge for apparel businesses to maintain a balance between fast growth and long-term survival $(\mathrm{Gu}, 2002)$. New ventures often face numerous

(c) The Author(s). 2018 Open Access This article is distributed under the terms of the Creative Commons Attribution 4.0 International License (http://creativecommons.org/licenses/by/4.0/), which permits unrestricted use, distribution, and reproduction in any medium, provided you give appropriate credit to the original author(s) and the source, provide a link to the Creative Commons license, and indicate if changes were made. 
disadvantages, including the higher costs of learning new skills, the lower quality of new products or services, the lack of a stable relationship with partners, and the lack of legitimacy in the marketplace (Hannan and Freeman, 1984). They have a low survival rate and many fail in their early stages (Shirokova and Shatalov, 2010). According to China News, over $80 \%$ of Chinese new ventures were reported to have failed in the first five years after opening (He, 2015).

Despite the importance of apparel new ventures in China, research is limited on analyzing factors impacting apparel new venture performance during the initial stage of business operations. In the new venture research field, it is found that firms' external networks, called "guanxi," are critical for new venture success in China, as "knowing the right people" is key (Zhuang, Xi and Tsang, 2010). Guanxi, as a central idea in Chinese society, describes the basic dynamic of personalized influence on social networks. It has a major influence on the management of businesses based in China (Zhuang, Xi, and Tsang, 2010). A positive link between guanxi and the reduction of transaction costs, overall firm efficiency, and performance has been noted by many researchers (Luo and Chen, 1997; Ngoma, 2016). Guanxi is often said to be the source of sustained competitive advantage for most Chinese businesses, especially for new ventures (Zou, Chen, and Ghauri, 2010). However, most guanxi research involving new ventures in China focuses on technology-related industries and export ventures, whose operations and measures of performance are fundamentally different from those of the apparel industry $\mathrm{Su}, \mathrm{Du}, \mathrm{Sohn}$, and $\mathrm{Xu}, 2017$; Li and Zhang, 2007). Past studies into the networks of relationships relied upon by new ventures have investigated many factors that may not apply to Chinese apparel new ventures. Given the unique characteristics of the Chinese apparel industry, (a) there is little basis for this view for apparel new ventures, and (b) there is a limited understanding on how guanxi factors into the success of these apparel new ventures.

Based on this background, we followed Hunt's (2002) procedure to explore how guanxi impacts Chinese apparel new ventures-specifically, an exploratory, sequential, mixed-methods approach (see Fig. 1 for the research flow of this study). With few past studies focused on Chinese apparel new ventures, a mixed-method approach can expand the breadth, depth, and range of the research by incorporating different methods and different avenues of inquiry, resulting in more comprehensive results (Creswell, 2013). By combining both qualitative and quantitative data, we were able to generate deeper insights on how guanxi helps Chinese apparel new ventures achieve success. This method allowed us to interpret the same phenomena from multiple aspects to maximize the strengths and reduce the limitations of single methods. Under this approach, the qualitative stage focused on developing relevant categories and themes as the basis for a subsequent quantitative phase, which focused on evaluating the possibilities of generalizing the qualitative results (Creswell and Clark, 2011; Teddlie and Tashakkori, 2009). That is, qualitative data provides greater depth of understanding of the

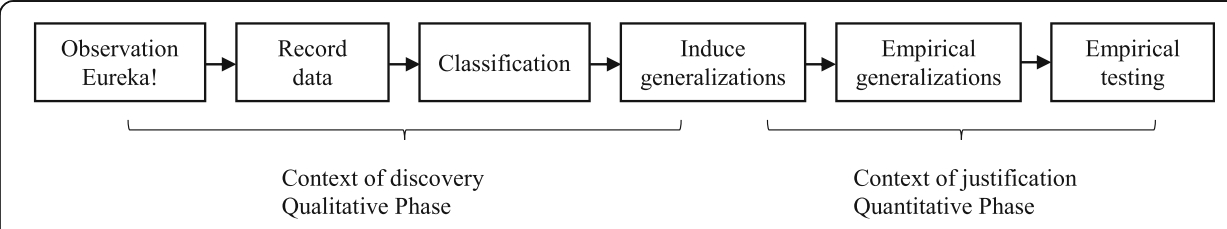

Fig. 1 Research Flow of This Study: Adapted from Hunt (2002) 
role guanxi plays in the success of Chinese apparel new ventures and helps identify variables impacting their performance. Quantitative data generalizes exploratory findings and provides a broader understanding to tell the complete picture. The next section offers a discussion of relevant literature and is followed by sections on research methods, results, and conclusions.

\section{Literature review}

\section{Resource-based view of the firm and social network theory}

To gain a deeper understanding of the relevant factors involved, Barney's (1991) resource-based view of the firm was used as a theoretical framework. According to this view, a firm is configured by various sets of unique, costly-to-copy, and rare resources that the firm possesses. These resources would help the firm gain a competitive advantage and, in turn, superior performance. This theory explains what the sources of a firm's competitive advantage are and why certain firms produce different levels of performance from others. From the resource-based theory, firms' external networks, especially for new ventures, are important resources for firms' success, as has been confirmed by many scholars (Dong, 2000; Coviello and Munro, 1995; Zhao and Aram, 1995; Hansen, 1995). When organizations face the uncertainty of resource exchange and an external competitive environment, they tend to establish various connections with key resource providers in the external network in order to stabilize their input and output (Salancik and Pfeffer, 1978). Especially in the information and Internet age, or the era of the knowledge economy, firms obtain more external resources and achieve higher levels of performance under lower levels of risk through the effective use of various strategic network relationships, and this has become more and more important for the development of a modern business strategy.

Successful firms take advantage of sharing their network resources and utilizing combined skills and tacit knowledge, creating "knowledge spillovers" (Ahuja, 2000). In addition, networks may be viewed as a gateway for exploring external opportunities or as an interface between firm-specific constraints and outside alternatives that may help relieve the constraints ( $\mathrm{Yu}, 2012)$. That is, a firm's external network is considered a unique, rare, and costly-to-copy resource by which the firm is configured. This network helps new ventures reduce business uncertainties and improve their decision-making processes.

Specifically focusing on the firms' external relationships as a key resource, the social network theory addresses a dynamic process by which a firm obtains, reaches, shares, or creates a bundle of valuable resources through its outside networks (Ahuja, 2000). In this theory, relationships are viewed in terms of nodes and ties; the nodes refer to the individuals within a network, and ties refer to the relationships between the individuals (Granovetter, 2005). Such social networks in the form of collaborations are used by businesses to gain access to up-to-date technology and market information (Wonglimpiyarat, 2007); they are also useful in knowledge transfer (Obstfeld, 2005; Reagans and McEvily, 2003).

In this light, new ventures can seek to enlarge their networks to get crucial information and other resources from knowledgeable others. They can also position themselves within a social network to shorten the path to knowledgeable others to get what they need 
(Blau, 1977; Burt, 1992). In addition, social network theory (Churchill, Carsrud, Gaglio, and Olm, 1987) provides a rationale for the important role of the founder's personal network for new venture performance. According to Churchill, Carsrud, Gaglio, and Olm (1987), the basic assumption of social network theory is that the founder is embedded in a complex set of social networks that either facilitate or inhibit venture development by facilitating or inhibiting effective linkages between the founder and the required resources and available economic opportunities. Therefore, a firm's network is "expanded to include not only a firm's but also the founder's set of relationships, both horizontal and vertical, with other organizations-be they suppliers, customers, competitors, or other entities" (Gulati, Nohria, and Zaheer, 2000: p. 203).

However, much of the research surrounding the social network theory was conducted within Western society, which views relationships as more surface-level, offering an impersonal role in shaping larger business relationships (Yum, 1988). In China, guanxi plays a much more central and personal role in shaping social business relations. Cross-cultural differences have impacted the values and behaviors expressed in Chinese business relations (Yang, 2011).

\section{Firms' networks (Guanxi) in China}

Deeply embedded from the collectivist cultural background, guanxi, or "knowing the right people," is one of the keys for success in China (Zhuang, Xi, and Tsang, 2010). Guanxi, as a central idea in Chinese society, describes the basic dynamic of personalized influence on social networks. It has a major influence on the management of businesses based in China (Zhuang, Xi, and Tsang, 2010). Guanxi relationships support high levels of personal trust and are associated with higher levels of firm performance in China. New-venture investors often rely on guanxi to reduce the many uncertainties they face in this business environment and to improve their business decisions (Zhuang, $\mathrm{Xi}$, and Tsang, 2010). With guanxi, individuals' social resources are used to develop and maintain social connections, sustaining the relationship established between individuals in business transactions (Carlisle and Flynn, 2005). Therefore, from a resource-based view of the firm, guanxi acts as a source of competitive advantage for firms in China (Zou and Gao, 2007).

In China's modern business settings, social network resources are considered extremely useful for better information sharing, better access to complementary resources and capabilities, increased sales of products and services, and so on (Zhuang, Xi, and Tsang, 2010). Moreover, social network resources are a critical factor to Chinese apparel new ventures. According to Ahlstrom and Bruton (2006), guanxi network connections among new ventures may play a significant role in helping them navigate and respond to the external uncertainties and changes in emerging economies. Through guanxi, new ventures could partially substitute for relatively weak formal institutions, such as the market for corporate control and the rule of law (Butler, Brown, and Chamornmarn, 2003), and by offering some protection from government interference (Peng, 2003).

Social network resources can also influence the performance of Chinese apparel new ventures. For example, suppliers can provide high-quality and low-cost fabric. A consulting company can help train sales assistants. The Ministry of Commerce can give political support, such as temporary tax immunity during the initial years after start up. 
The shopping mall can provide a better store location with more traffic flow. It is necessary to pay attention to the relationships of networks in order to better achieve information sharing, access to complementary resources and capabilities, product sales goals and so on. Establishing the contract, communicating with each other, trust, and coordination with external bodies are very important for Chinese apparel new venture development (Forza and Vinelli, 1997). Therefore, firms' network relationships, which also refer to guanxi in Chinese, are an important factor for Chinese apparel new venture performance. Yet, how such guanxi helps apparel new ventures' initial success in China is yet to be examined. To fill this gap, the study developed a mixed-method research plan to discover and test key factors that could be helpful for apparel new ventures' success in China.

\section{Qualitative phase \\ Method}

In light of the lack of previous research focusing on Chinese apparel new ventures, a qualitative research method using semi-structured, in-depth interviews with open-ended questions was employed, as in-depth interviews are recommended for uncovering valuable insights, experiences, and perspectives that are difficult to obtain through other research techniques (Creswell and Clark, 2011). After approval from the university's Institutional Review Board, the researchers interviewed representatives from 16 Chinese apparel companies through the purposive sampling technique. All participants were founders or senior managers who were qualified to offer information concerning their company's experiences in the first five years of business establishment. Interviews were conducted between December 2013 and February 2014. Each interview took approximately $60 \mathrm{~min}$ and was conducted at the offices of the participants or by Skype, an online video-conference tool. The entire interviews were conducted in Chinese. The interview transcripts were transcribed in Chinese initially. Then the research team translated the transcriptions into English. The English version was then back-translated into Chinese to ensure the quality of Chinese-to-English translation. The English-transcribed data were then used for further data analysis. Table 1 shows the demographic characteristics of the participants.

\section{Findings}

The interview data were coded by emergent themes using constant comparative analysis, which allowed similarities and differences to develop among the cases, and then the results were interpreted (Creswell and Clark, 2011). The qualitative analysis of the data allows for the establishment of three themes and their respective hypotheses. Participants described three major characteristics of guanxi: (a) founders' personal networks transformed to firms' networks [12 out of 16]; (b) information sharing and communication with business partners [10 out of 16]; and (c) long-term relationships with business partners [8 out of 16$]$.

\section{Guangxi: Founders' personal networks into firms' networks}

A majority of the participants (12 out of 16) stated that, with "founders' family members' and friends' relationships" [P8], new ventures get "preferential taxing policy" 
Table 1 Demographic Characteristics of Participants

\begin{tabular}{|c|c|c|c|c|c|c|c|}
\hline No. & $\begin{array}{l}\text { Position } \\
\text { Level }\end{array}$ & $\begin{array}{l}\text { Product } \\
\text { Category }\end{array}$ & $\begin{array}{l}\text { Year } \\
\text { Established }\end{array}$ & Target Market & Ownership & $\begin{array}{l}\text { Employment } \\
\text { Size }\end{array}$ & $\begin{array}{l}\text { Location } \\
\text { (Province) }\end{array}$ \\
\hline P1 & $\begin{array}{l}\text { Human } \\
\text { Resource } \\
\text { Manager }\end{array}$ & Men's Clothing & 1994 & Mass Market & Private & $\begin{array}{l}1000 \text { to } \\
1499\end{array}$ & Beijing \\
\hline P2 & $\begin{array}{l}\text { General } \\
\text { Manager }\end{array}$ & $\begin{array}{l}\text { Women's } \\
\text { Clothing }\end{array}$ & 2012 & Designer Brand & Private & 20 to 99 & Beijing \\
\hline P3 & Founder & $\begin{array}{l}\text { Women's } \\
\text { Clothing }\end{array}$ & 2010 & $\begin{array}{l}\text { Mass Market, E- } \\
\text { commerce }\end{array}$ & Private & $\begin{array}{l}1000 \text { to } \\
1499\end{array}$ & Beijing \\
\hline P4 & Co-founder & $\begin{array}{l}\text { Women's } \\
\text { Clothing }\end{array}$ & 2000 & Mass Market & Partnership & 20 to 99 & Guangdong \\
\hline P5 & $\begin{array}{l}\text { CEO } \\
\text { assistant }\end{array}$ & $\begin{array}{l}\text { Women's } \\
\text { Clothing }\end{array}$ & 1997 & Mass Market & Private & $\begin{array}{l}1000 \text { to } \\
1499\end{array}$ & Beijing \\
\hline P6 & Founder & $\begin{array}{l}\text { Women's } \\
\text { Clothing }\end{array}$ & 2009 & High End & Private & 20 to 99 & Beijing \\
\hline P7 & $\begin{array}{l}\text { CEO } \\
\text { assistant }\end{array}$ & $\begin{array}{l}\text { Clothing } \\
\& \text { Shoes }\end{array}$ & 2008 & High End & Private & 500 to 999 & Beijing \\
\hline P8 & Founder & $\begin{array}{l}\text { Women's } \\
\text { Clothing }\end{array}$ & 1996 & Mass Market & Private & $\begin{array}{l}1000 \text { to } \\
1499\end{array}$ & Guangdong \\
\hline P9 & Founder & $\begin{array}{l}\text { Women's } \\
\text { Clothing }\end{array}$ & 1997 & Mass Market & Private & 100 to 499 & Shanghai \\
\hline P10 & $\begin{array}{l}\text { Marketing } \\
\text { Manager }\end{array}$ & $\begin{array}{l}\text { Men's } \\
\text { Clothing }\end{array}$ & 1990 & Mass Market & Public & $\begin{array}{l}5000 \text { or } \\
\text { more }\end{array}$ & Fujian \\
\hline P11 & $\begin{array}{l}\text { Marketing } \\
\text { Manager }\end{array}$ & $\begin{array}{l}\text { Men's } \\
\text { Clothing }\end{array}$ & 1976 & Mass Market & Public & $\begin{array}{l}5000 \text { or } \\
\text { more }\end{array}$ & Jiangsu \\
\hline P12 & $\begin{array}{l}\text { General } \\
\text { Manager }\end{array}$ & $\begin{array}{l}\text { Women's } \\
\text { Clothing }\end{array}$ & 2003 & Mass Market & Private & $\begin{array}{l}1000 \text { to } \\
1499\end{array}$ & Zhejiang \\
\hline P13 & Founder & $\begin{array}{l}\text { Women's } \\
\text { Clothing }\end{array}$ & 2001 & Mass Market & Partnership & $\begin{array}{l}1000 \text { to } \\
1499\end{array}$ & Shanghai \\
\hline P14 & Founder & $\begin{array}{l}\text { Women's } \\
\text { \& Men's Clothing }\end{array}$ & 1995 & Mass Market & Public & $\begin{array}{l}5000 \text { or } \\
\text { more }\end{array}$ & Zhejiang \\
\hline P15 & $\begin{array}{l}\text { Product } \\
\text { Manager }\end{array}$ & $\begin{array}{l}\text { Sports } \\
\text { Clothing }\end{array}$ & 1990 & Mass Market & Public & $\begin{array}{l}5000 \text { or } \\
\text { more }\end{array}$ & Beijing \\
\hline P16 & Founder & $\begin{array}{l}\text { Women's } \\
\text { clothing }\end{array}$ & 2009 & High End & Sole trader & 20 to 99 & Shanghai \\
\hline
\end{tabular}

[P12], "monetary support" [P2], and other benefits. In Participant 5's case, the founder "keeps a good relationship with a member of the Chinese People's Political Consultative Conference (CPPCC), and therefore, the company operates quite well in Beijing." That is, founders, acting in the role of resource coordinators and agents for a new venture (Bhide, 2000; Kirzner, 1973) often bring their personal social networks to the firm as their most valuable asset to provide resources necessary for successful emergence (Aldrich, Rosen, and Woodward, 1987; Hite, 1999; Larson and Starr, 1993). The results were consistent with Nohria (1992) who argued that, to establish a firm, founders look for relationships on the basis of common interest or experience in building and running a business and obtaining resources such as information, property, capital, or credit. In addition, the result supports the argument that it is the responsibility of top managers to develop their firm's capacity to build and maintain a guanxi network, which works at both the business level and the personal level to help the firm capitalize on opportunities and control risks (Xia, Qiu, and Zafar, 2007). 


\section{Guanxi: Unique benefits from information sharing}

Participants also expressed that obtaining information and effective communication are key success factors for new ventures. Sharing information and communications with partners assists participants in developing knowledge of "industry situations through first-hand information sources" [P13] or "turns of events and exclusive new trends" [P2]. In Participant 8's words: "Sometimes the government puts forward some policy guidance; your relationship with the government may make you win or lose some opportunities for company development. In terms of start-up funding, in fact, that has a close relationship with the government. You know that sometimes there are things that we cannot get through the normal way, but it will be relatively easy to get with the help of others. That is guanxi."

That is, social network resources in China are extremely useful for better information sharing, better access to complementary resources and capabilities, increased sales of products and services, and so on. More specifically, establishing both formal and informal contracts, communicating with each other within the supply chain, building trust, and coordinating with external bodies are among the key examples of today's social network resources in China (Zhuang, Xi, and Tsang, 2010).

\section{Guanxi: Long-term satisfying relationships}

Finally, 8 of the 16 participants mentioned long-term relationships with business partners as one of the key factors for their success. Sometimes, companies' "old and long-term partners" [P11] could help by "extending payback period" [P14], "getting discounts" [P14], "acquiring administrative approvals" [P1], and "gaining preferential treatment for a good location" [P16] for new store openings. Such benefits, however, require a long period of relationship facilitation. Participant 3 said “we certainly cannot say that guanxi didn't help us. One of my suppliers has been working with me for almost 10 years. He helped me extend payback period last year. Without this long-term relationship, it would have been impossible to survive through the hard times. Of course, if he is in trouble, I will definitely help him without hesitation." Long-term relationships that indicate the potential for cooperation, goal sharing and risk sharing with supply-chain members could offer important sustainable competitive advantages to firms (Ganesan, 1994). All parties will tend to expect that their own performance is dependent on the performance of the relationship, and thus, in addition to benefiting their own results, the relationship will result in joint benefits. Relationships based on a long-term orientation allow new ventures to sacrifice short-term gains in favor of long-run profitability and maintenance of the relationship, long-term goals and long-run concessions (Ganesan, 1994).

\section{Quantitative phase}

With the three key themes that emerged from the previous phase, we then developed study hypotheses that could be tested empirically and generalized for a broader understanding of Chinese apparel new ventures success.

\section{Hypothesis development}

Even though guanxi is a well-researched construct, the means by which it has been most commonly measured did not offer to capture the major themes that emerged in 
the qualitative phase of this study. For example, one study posits and examines a measurement scale for guanxi based on three Chinese relational constructs-ganqing, renqing and xinren (Yen, Barnes, and Wang, 2011). Another study suggested seven dimensions of guanxi including favors, mutual benefits, reciprocity, personal interaction, harmony, face, and differentiation (Lee and Dawes, 2005). However, neither of these scales captured the construct of relationships among firms that was emphasized by the participants. The gist of the three themes that emerged from the previous phase were reviewed with the existing guanxi literature, and the concept of firm network relationship quality was identified as a measurable, and therefore testable, construct. Firm network relationship quality has been discussed as a critical concept when understanding guanxi building and management in the guanxi literature (Chen and Chen, 2004). Relationship quality refers to the common cognitive appraisal given by relationship subjects in the startup process (Yu, 2007). It also refers to the intangible benefits of enhancing trust and commitment, and maintaining long-term relationships (Liu and Yao, 2005). The quality of relationship reflects the intensity of information sharing, communication quality, long-term orientation, and satisfaction with the relationship between new ventures and their supply-chain partners, which is consistent with interview themes. In this light, four dimensions of the quality of relationship can be used to measure the impact of guanxi on Chinese apparel new venture performance appropriately in the quantitative phase.

In research by Dwyer, Schurr, and Oh (1987) about the evolution of relationships in supply-chain partners, it was pointed out that mutual commitment, satisfaction, and minimal opportunistic tendencies impact the establishment, functioning, and sustainable development of the relationship. However, only analyzing how these single factors influence the quality of relationships was not sufficient. Therefore, researchers proposed that relationship quality is a high order factor, including multi-dimensional variables (Crosby, Evans, and Cowles, 1990; Naudé and Buttle, 2000; Walter, Muller, Helfert, and Ritter, 2003). In fact, four dimensions from Lages, Lages, and Lages's (2005) research were found to be relative to our study and were selected to measure the firm network relationship quality: (a) amount of information sharing in the relationship, (b) communication quality of the relationship, (c) long-term relationship orientation, and (d) satisfaction with the relationship.

\section{Amount of information sharing}

As revealed from the second theme, information sharing is considered a key factor for the success of Chinese apparel new ventures. Shin, Ishman, and Sanders (2007) investigated the influence of cultural factors on information sharing in China and found guanxi had a significant impact on information sharing. Cannon and Homburg (2001) stated that the amount or frequency of information sharing, which refers to how long and how often the partners openly enter into contact with each other, is very important in the global supply chain (Farace, Monge, and Russell, 1977). Therefore, for apparel new ventures that must work with complex and multiple supply-chain members, sharing confidential information, discussing strategic issues, or conducting frequent conversations with supply-chain members can strengthen relationships. By receiving information, supply-chain partners may more easily predict a new venture's future plans and adapt its own strategy to incur lower 
costs. It could help to reduce the risk of uncertainties and to make use of the information more effectively (Cannon and Homburg, 2001). Therefore, it was hypothesized that:

H1. Amount of information sharing positively affects Chinese apparel new ventures' competitive advantages.

\section{Communication quality of the relationship}

A major problem among relationship parties is communication difficulties (Mohr and Nevin, 1990). Communication is not only a process for people to exchange information, but for them to decipher each other's codes. The two-way process in communication helps people to achieve shared understanding (Duncan and Moriarty, 1998). Interview participants pointed out the importance of communication. In China, effective communication is challenging since communication features vary in different provinces or areas. If the wrong channel was picked or codes were misunderstood in communication, the quality of the relationship would be negatively impacted (Yu, 2007).

Communication can be considered the most important element in successful inter-firm exchange, as "the most carefully designed relationship will crumble without good, frequent communication" (Bleeke and Ernst, 1993, p. 14). It was found that highly interactive firms usually invested both managerial and financial resources to maintain and develop communication networks with their supply-chain partners. In order to have strong relationships and better performance, firms might want to consider these communication networks as key and beneficial resources (Calantone and Schatzel, 2000). Conversely, ineffective communication may lead to conflict due to misinterpretation and reciprocal dissatisfaction (Calantone and Schatzel, 2000). Therefore, it was hypothesized that:

H2. Communication quality of the relationship positively affects Chinese apparel new ventures' competitive advantages.

\section{Long-term relationship orientation}

The third theme revealed the significant role of long-term relationship orientation. Long-term relationships that indicate the potential for cooperation, goal sharing and risk sharing with supply-chain members could offer important sustainable competitive advantages to firms (Ganesan, 1994). All parties will tend to expect that their own performance is dependent on the performance of the relationship, and thus, in addition to benefiting their own results, the relationship will result in joint benefits. Hence, Ganesan (1994) defined long-term relationship orientation as the perception of mutual dependence that joint relationship outcomes are related to future rewards. Relationships based on a long-term orientation allow new ventures to sacrifice short-term gains in favor of long-run profitability and maintenance of the relationship, long-term goals and long-run concessions. In its opposite pole, a short-term-oriented relationship, firms are more interested in current-period opportunities and outcomes rather than future goals and outcomes (Ganesan, 1994). Lee and Dawes (2005) posited long-term orientation as an important aspect of guanxi that results in trust between parties in the supply chain. Therefore, it was hypothesized that: 
H3. Long-term relationship orientation positively affects Chinese apparel new ventures' competitive advantages.

\section{Satisfaction with the relationship}

Satisfaction with the relationship is defined as the "cognitive and affective evaluation based on personal experience across all [...] episodes within the relationship" during past interactions with the firm (Roberts, Varki, and Brodie, 2003, p. 175). Satisfaction with the relationship is considered a key dimension of relationship quality because it has been confirmed that more satisfied buyers have higher quality relationships with suppliers. For example, the manufacturer's role performance has a positive impact on dealer satisfaction with the manufacturer (Frazier, 1983). If a channel member contributes largely to the other member's goals, the second member will consequently be more satisfied with the overall relationship with the first (Kumar, Stern, and Achrol, 1992). Chinese apparel new ventures were expected to have similar perceptions regarding supply chain partners-that they tend to be more knowledgeable about the roles of new ventures and more perceptive about the quality of the relationship. Therefore, it was hypothesized that:

H4. Satisfaction with the relationship positively affects Chinese apparel new ventures' competitive advantages.

\section{Competitive advantages and new venture performance}

Additionally, according to the resource-based view of the firm, a firm has a competitive advantage when it has unique resources and capabilities that are rare, that are not able to be implemented by other competitors, and that allow the firm to provide a competitive offer to the market (Barney, 1991). In the context of Chinese apparel new ventures, the quality of firm network relationships can be considered a critical resource to help achieve competitive advantages and, in turn, achieve better performance. Therefore, it was hypothesized that:

H5. Chinese apparel new ventures' competitive advantages positively affect their venture performance (Fig. 2).

\section{Method}

To test these hypotheses, an online survey was conducted in order to provide empirical evidence for this research. Online surveys are useful for targeting specific populations at a time and place of the participants' convenience (Creswell and Clark, 2011). Due to the difficult-to-reach population of study subjects, the purposive sampling technique was used. Data were collected from February 2015 to March 2015 by So Jump, a professional survey company in China. As a result, 210 usable responses were collected for further data analysis.

The quality of firm network relationships was measured through the relationship quality scale developed by Lages et al. (2005), including: (a) amount of information sharing, (b) communication quality of the relationship, (c) long-term relationship orientation, and (d) satisfaction with the relationship. The scale for amount of information 


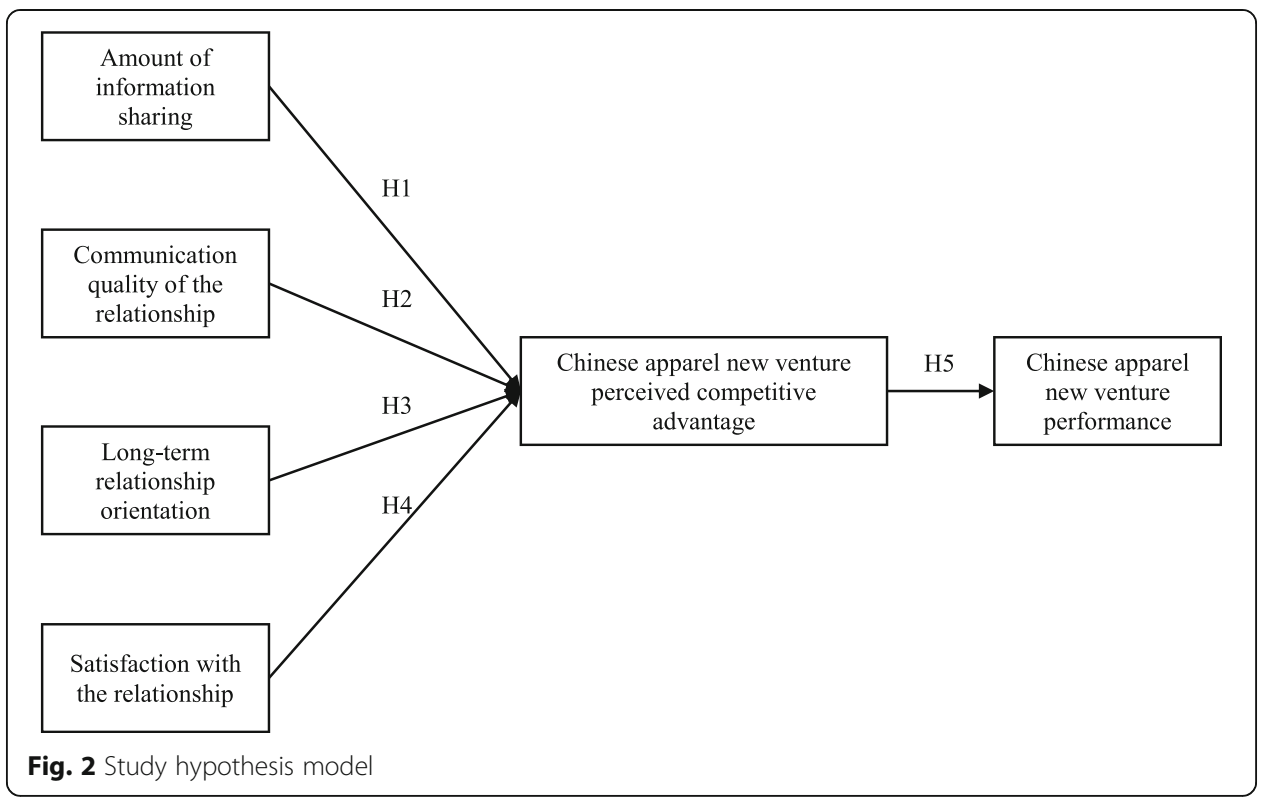

sharing is adapted from Cannon and Homburg (2001) and includes three items. An example is "My company's partners frequently discuss strategic issues with us." The scale for communication quality of the relationship is adapted from Menon, Bharadwaj, Adidam, and Edison (1999), and Menon, Bharadwaj, and Howell (1996). It includes four items. A sample item is "The objectives and goals of business strategies are clearly communicated to all of my company's partners." The scale for long-term relationship orientation is adapted from Ganesan (1994) and includes four items. A sample item is "I believe that over the long run, the relationship with my company's partners will be profitable." The scale for satisfaction with the relationship is adapted from Kumar, Stern, and Achrol (1992) and includes three items. One example is "Overall, the results of our relationship with my company's partners are far short of expectations." Additionally, since this scale is adopted for the first time in the apparel context, in order to be suitable in precisely the way the study demands, some items were modified by following De Vellis and Dancer's (1991) principle. For example, "This importer frequently discussed strategic issues with us" was modified to "My company's partners frequently discuss strategic issues with us." Measurements were made on a five-point Likert scale ranging from 1 (strongly disagree) to 5 (strongly agree). The items were scored so that a higher score indicated higher quality of firm network relationships.

New venture performance in this study was assessed using self-reported measures of performance from four determinants that have proved reliable in past research on entrepreneurship (Brush and Vanderwerf, 1992). Respondents were asked to honestly answer a set of questions that compared the performance of their venture to an industry average in the previous calendar year on a five-point, Likert-type scale ranging from $1=$ "Clearly below average" to 5 = "Clearly above average" for the following indicators: profitability, sales volume, market share, and productivity. All the scales and questions were translated to Chinese first, and then translated back from Chinese to English by a professional translator who was not given any reference about the original English version in order to verify the quality of the translation. 


\section{Data analysis and findings}

Of the sample of 210 respondents, 80 were male (38.1\%) and 130 were female (61.9\%). Business sectors represented in the sample were 68 retail (32.5\%), 81 wholesale (38.4\%), and 133 manufacturing (63.3\%). The breakdown of educational backgrounds of the participants was: 1 less than high school (0.5\%), 6 high school diploma (2.9\%), 189 college degree or bachelor's degree (90\%), and 14 graduate degree (6.7\%). Descriptive means and standard deviations were analyzed for the continuous demographic characteristic variables. Age of participants ranged from 24 to 46, with the mean age between 33 and 34 years old. The length in years since company establishment was between 1 and 5 , with a mean of 3.87 years. The number of employees ranged from 2 to 2000, with a mean number of 184 to 185 . Years of work experience of the participants ranged from 1 to 21 , with a mean of 9.81 years. Specifically, years of experience in the Chinese apparel industry ranged from 1 to 21 , with a mean of 7.96 years (Table 2).

For hypothesis testing, AMOS 24 with maximum-likelihood estimation was used to conduct a path analysis of the hypothesized relations with mean values of each variable. Path analysis is a special case of structural equation modeling, which is a flexible and powerful statistical methodology used to examine the relationships between the variables, especially when the researchers have sample size limitations (Garson, 2008; Wright, 1934). Criteria for acceptable model fit have ranged from comparative fit index (CFI) above 0.90 and root mean square error of approximation (RMSEA) under 0.10.

Table 2 Demographic Characteristics of Participants $(n=210)$

\begin{tabular}{|c|c|c|}
\hline Variable & $n$ & Percent \\
\hline \multicolumn{3}{|l|}{ Gender } \\
\hline Male & 80 & $38.1 \%$ \\
\hline Female & 130 & $61.9 \%$ \\
\hline Total & 210 & $100 \%$ \\
\hline \multicolumn{3}{|l|}{ The sector of business ${ }^{1}$} \\
\hline Retail & $68 / 210$ & $32.5 \%$ \\
\hline Wholesale & $81 / 210$ & $38.4 \%$ \\
\hline Manufacturing & $133 / 210$ & $63.3 \%$ \\
\hline \multicolumn{3}{|l|}{ Educational Background } \\
\hline Less than high school & 1 & $.5 \%$ \\
\hline High school diploma & 6 & $2.9 \%$ \\
\hline College degree or bachelor's degree & 189 & $90 \%$ \\
\hline Graduate degree & 14 & $6.6 \%$ \\
\hline Total & 210 & $100 \%$ \\
\hline Variable & M & $S D$ \\
\hline \multicolumn{3}{|l|}{ Participants } \\
\hline Age & 33.60 & 4.75 \\
\hline Years of work experience & 9.81 & 4.02 \\
\hline Years of experience in the Chinese apparel industry & 7.96 & 4.20 \\
\hline \multicolumn{3}{|l|}{ Companies } \\
\hline Years since company establishment & 3.87 & 1.06 \\
\hline Number of employees & 184 & 226.71 \\
\hline
\end{tabular}

Note: Participants were asked to choose more than one option if appropriate 
Despite the flexibility that the path analysis offers, we also wanted to compare relative importance of the study predictors on the dependent variable. We performed dominance analysis to compare the relative importance of predictors. Based on an examination of the $\mathrm{R}^{2}$ values for all possible subset models, the relative weights of each dimension of the quality of relationships were examined (Azen and Budescu, 2003). According to Field (2009) and Hooper, Coughlan, and Mullen (2008), the data met guidelines for univariate normality and multivariate normality, and there were no multivariate outliers. Additionally, no multicollinearity or construct redundancy was indicated. The data did not deviate from linearity and homoscedasticity (indicated by standardized residuals plotted against standardized predicted values). Table 3 reports the means, standard deviations, zero-order correlations, and Cronbach's alpha of the study variables.

\section{Results}

The hypothesized model fit the data well: $x^{2}(6, N=210)=27.920, p<.000$; CFI $=0.996$; $\mathrm{RMSEA}=.042, \mathrm{AIC}=39.455 ; \mathrm{BIC}=96.356$. The results supported hypotheses $2,3,4$ and 5 ( $\beta=0.329, p<0.05 ; \beta=0.305, p<0.05 ; \beta=0.173, p<0.05)$. It was found that communication quality of the relationship, long-term relationship orientation, and satisfaction with the relationship all have a significantly positive impact on perceived Chinese apparel new venture competitive advantages. Surprisingly, amount of information sharing did not demonstrate statistical significance on Chinese apparel new ventures' competitive advantages when other relationship-quality dimensions are included in the model. One possible reason might be that other variables in the model have accomplished the predictive work for this non-significant variable (Meyers, Gamst, and Guarino, 2006). Future research would be needed to investigate the unique contribution of amount of information sharing on the perceived quality of firms' network relationships. Finally, Chinese apparel new ventures' competitive advantages positively affected Chinese apparel new venture performance $(\beta=0.617, p<0.001)$, which was expected and aligned with Barney's (1991) resource-based theory. Table 4 shows parameter estimates, $t$-values, and significance levels.

Dominance analysis was conducted to compare the relative weights of each dimension of the quality of relationships (Azen and Budescu, 2003). The general measure represents the average difference in fit between all subset models (of equal size). $X_{2}$ (communication quality of the relationship) generally dominated all predictors and had the largest impact on perceived competitive advantages of Chinese apparel new ventures. $X_{3}$ (long-term relationship orientation) was found to dominate $X_{1}$ (amount of information sharing) and $X_{4}$

Table 3 Descriptive statistics, correlations, and Cronbach's alpha

\begin{tabular}{|c|c|c|c|c|c|c|c|c|}
\hline Variable & Mean & s.d. & 1 & 2 & 3 & 4 & 5 & Cronbach's alpha \\
\hline 1. Amount of information sharing & 3.819 & 0.636 & & & & & & .717 \\
\hline $\begin{array}{l}\text { 2. Communication quality of the } \\
\text { relationship }\end{array}$ & 4.191 & 0.532 & $.479^{* *}$ & & & & & .686 \\
\hline 3. Long-term relationship orientation & 4.193 & 0.495 & $.412^{* *}$ & $.545^{* *}$ & & & & .678 \\
\hline 4. Satisfaction with the relationship & 3.737 & 0.729 & $.406^{* *}$ & $382^{* *}$ & $.409^{* *}$ & & & 669 \\
\hline 5. Competitive Advantages & 3.986 & 0.514 & $.355^{* *}$ & $.562^{* *}$ & $.555^{* *}$ & $.424^{* *}$ & & .819 \\
\hline 6. New Venture Performance & 3.670 & 0.544 & $.298^{* *}$ & $.364^{* *}$ & $.413^{* *}$ & $.346^{* *}$ & $.617^{* *}$ & .799 \\
\hline
\end{tabular}

Note: ${ }^{* *}$ is significant at $p<.05$ 
(satisfaction with the relationship). $X_{4}$ (satisfaction with the relationship) dominated $X_{1}$ (amount of information sharing). That is, communication quality of the relationship is the strongest predictor, followed by long-term relationship orientation and satisfaction with the relationship (Table 5).

\section{Discussion}

Overall, both the qualitative and quantitative research showed that guanxi could produce a sustained competitive advantage for Chinese apparel new ventures. The qualitative study results suggested the hypotheses of this study apply to the study population. This study provides several important contributions to the new venture study field, particularly with regard to Chinese apparel new ventures. Indeed, new ventures that show better communication with partners could more easily predict others' plans, adapt appropriate strategies to incur lower costs, and increase business efficiency, in turn resulting in higher level performance. Both long-term relationships and satisfied partners could benefit new venture performance. This result is consistent with social network theory and shows that competitive advantage may be achieved by firms' social network resources. In particular, for Chinese apparel new ventures, guanxi, which creates network relationships of good quality, is an important resource of sustained competitive advantage for established businesses in China.

Data showed that the resource-based theory of the firm is a useful theoretical framework to analyze why guanxi can offer a sustained competitive advantage and be a critical resource for Chinese apparel new ventures. Social network theory was found to be an important complementary theory for the resource-based theory of the firm in Chinese apparel new venture research. From the perspective of Chinese society, social network theory from Western culture was revisited as a Chinese version of guanxi, which extends social networks to both the firm's and the founder's set of relationships. Additionally, the study findings showed three critical dimensions of the quality of firm networks for Chinese apparel ventures. Communication quality, maintaining a long-term relationship, and satisfaction with the relationship were found to be key dimensions of the study participants' firm network, while the amount of information sharing through the network was found statistically insignificant in the study model. Despite the fact that, in the information and Internet age, information sharing may be useful to partner relationships, this dimension was not shown to contribute to the model in this study. One reason

Table 4 Parameter Estimates, t-Values, and Significance Levels $(n=210)$

\begin{tabular}{|c|c|c|c|}
\hline Paths in the Model & $\begin{array}{l}\text { Standardized Parameter } \\
\text { Estimates }\end{array}$ & $\begin{array}{l}\text { t- } \\
\text { value }\end{array}$ & $\begin{array}{l}p^{-} \\
\text {value }\end{array}$ \\
\hline $\begin{array}{l}\text { Amount of information sharing } \rightarrow \\
\text { Chinese apparel new ventures' competitive advantages }\end{array}$ & .002 & .036 & .971 \\
\hline $\begin{array}{l}\text { Communication quality of the relationship } \rightarrow \\
\text { Chinese apparel new ventures' competitive advantages }\end{array}$ & .329 & 4.929 & .001 \\
\hline $\begin{array}{l}\text { Long-term relationship orientation } \rightarrow \\
\text { Chinese apparel new ventures' competitive advantages }\end{array}$ & .305 & 4.665 & .001 \\
\hline $\begin{array}{l}\text { Satisfaction with the relationship } \rightarrow \\
\text { Chinese apparel new ventures' competitive advantages }\end{array}$ & .173 & 2.864 & .004 \\
\hline $\begin{array}{l}\text { Chinese apparel new ventures' competitive advantages } \rightarrow \text { Perceived } \\
\text { Chinese apparel new venture performance }\end{array}$ & .617 & 11.347 & .001 \\
\hline
\end{tabular}


Table 5 Dominance Analysis

\begin{tabular}{|c|c|c|c|c|c|}
\hline \multirow{2}{*}{$\begin{array}{l}\text { Subset model } \\
(X)\end{array}$} & \multirow[t]{2}{*}{ rho $^{2} Y . X$} & \multicolumn{4}{|c|}{ Additional contribution of: } \\
\hline & & $\overline{X_{1}}$ & $x_{2}$ & $x_{3}$ & $X_{4}$ \\
\hline $\mathrm{k}=0 \&$ Null & 0 & 0.126 & 0.316 & 0.308 & 0.180 \\
\hline$x_{1}$ & 0.126 & - & 0.199 & 0.202 & 0.094 \\
\hline$x_{2}$ & 0.316 & 0.009 & - & 0.088 & 0.051 \\
\hline$x_{3}$ & 0.308 & 0.020 & 0.096 & - & 0.047 \\
\hline$x_{4}$ & 0.180 & 0.040 & 0.187 & 0.175 & - \\
\hline$k=1$ & & 0.023 & 0.161 & 0.155 & 0.064 \\
\hline$x_{1} x_{2}$ & 0.325 & - & - & 0.080 & 0.043 \\
\hline$x_{1} x_{3}$ & 0.328 & - & 0.077 & - & 0.033 \\
\hline$X_{1} X_{4}$ & 0.220 & - & 0.148 & 0.141 & - \\
\hline$x_{2} x_{3}$ & 0.404 & 0.001 & - & - & 0.024 \\
\hline$x_{2} X_{4}$ & 0.367 & 0.001 & - & 0.061 & - \\
\hline$X_{3} X_{4}$ & 0.355 & 0.006 & 0.073 & - & - \\
\hline$k=2$ & & 0.003 & 0.099 & 0.094 & 0.033 \\
\hline$x_{1} x_{2} x_{3}$ & 0.405 & - & - & - & 0.023 \\
\hline$X_{1} x_{2} X_{4}$ & 0.368 & - & - & 0.060 & - \\
\hline$X_{1} X_{3} X_{4}$ & 0.361 & - & 0.067 & - & - \\
\hline$x_{2} X_{3} X_{4}$ & 0.428 & 0.000 & - & - & - \\
\hline$k=3$ & & 0.000 & 0.067 & 0.060 & 0.023 \\
\hline$X_{1} X_{2} X_{3} X_{4}$ & 0.428 & - & - & - & - \\
\hline Overall Average & & 0.038 & 0.161 & 0.154 & 0.075 \\
\hline Percentage & & $9 \%$ & $38 \%$ & $36 \%$ & $18 \%$ \\
\hline
\end{tabular}

might be that amount of information sharing is not necessarily equal to key information sharing. Some confidential information, such as tax incentives or fire safety inspections without notice, is critical for Chinese apparel new ventures. However, this type of information cannot be shared very frequently. In addition, some aspects of information sharing might be covered by other predictors in the model. Further investigation is required to discover the role of information sharing for Chinese apparel new venture success.

According to the different culture and specific type of the industry, the necessity and importance of firms' networks could vary. Yum (1988) noted that Western societies emphasize short-term, symmetrical reciprocation in exchange relationships, while people in China consider long-term relationships and social networks into the unpredictable future. At the same time, $\mathrm{Yu}$ (2007) stated that those industries needed too much outside collaboration, and with simple distribution channels are less dependent on their external networks. On the other hand, some industries have complex distribution channels and need highly collaborative networks, such as the apparel industry or advertising agencies. New ventures in these industries are more likely to be influenced by the quality of firm network relationships (Yu, 2007).

\section{Conclusions}

This study provides empirical support for Chinese apparel new ventures to recognize the importance of the quality of firms' external network relationships. In particular, Chinese 
apparel new ventures may want to pay more attention to maintaining long-term relationships, increasing communication quality within the network, and achieving satisfaction with the relationship. For example, by providing higher quality products, showing mutual respect, building trust, or showing fairness and honesty, Chinese apparel new ventures could develop good relationships with partners. Both Chinese and Western supply-chain partners could have a better understanding from this research of the importance of firm network relationships of Chinese apparel new ventures. When coping with the critical business challenges of globalization and cross-cultural collaboration, the findings of this study are very useful for partners formulating and implementing appropriate strategies for working with Chinese apparel new ventures. Perhaps, when forming new firm network relationships with Chinese apparel new ventures, supply-chain partners may want to focus on the quality of communication and maintaining long-term firm relationships. Understanding the economic values of guanxi, Chinese apparel new ventures may want to improve network relationships to achieve greater competitive advantages.

In addition, this study showed firms' networks are an extremely important aspect of Chinese apparel new venture success. It is suggested that educators need to incorporate related content into their curricula. Since guanxi is very important for business success in China, it will be helpful to give students more chances to build their own network or at least have some practice with it. By using group study and role-play games, their communication and collaboration capability would be improved and they could gain a better understanding of guanxi and how guanxi and firm network relationships influence new venture success.

\section{Limitations and future research}

This study has several limitations that show the need for more investigations in future research. First, in analyzing data through path analysis, it was found that not all dimensions were captured. Although this study used Lages et al.'s (2005) scale that had previously tested as highly reliable, the "amount of information sharing" factor was not shown to contribute to the model. Further research could examine the Lages et al. (2005) scale and potentially revise the "amount of information sharing" items in the Chinese apparel new venture context. Second, this study shows one of the few cases where the relationship quality scale has been translated into Chinese and used in the context of Chinese apparel new ventures. Test results with new populations cross-culturally may show different factor structures. Further research is suggested to examine this scale and potentially revise the items for other contexts. Third, this research only collected data from founders in the Chinese apparel industry. How supply-chain partners view guanxi when they do business with Chinese apparel new ventures is unknown. Further research opportunities could compare the use and understanding of firms' external networks between new ventures and their supply-chain partners, especially how Western apparel companies make use of guanxi to benefit their business in China due to different cultural backgrounds. In addition, certain limitations existed due to the research design. The study's sample relied on purposive sampling, which may not be representative of the Chinese new venture founders population. Future research could aim to gather a larger number of participants, in addition to utilizing a randomized sampling technique. 
Acknowledgements

We thank the anonymous referees for their useful suggestions.

\section{Funding}

The authors received no financial support for the research, authorship, and/or publication if this article

\section{Availability of data and materials}

Survey data will be shared.

\section{Authors' contributions}

LZ and JH designed the study, developed the methodology, performed the analysis, and wrote the manuscript. LZ collected the data. Both authors read and approved the final manuscript.

\section{Competing interests}

The authors declare that they have no competing interests.

\section{Publisher's Note}

Springer Nature remains neutral with regard to jurisdictional claims in published maps and institutional affiliations.

Received: 20 October 2017 Accepted: 16 May 2018

Published online: 28 May 2018

\section{References}

Ahlstrom, D, \& Bruton, GD. (2006). Venture capital in emerging economies: Networks and institutional change. Entrepreneurship Theory and Practice, 30(2), 299-320.

Ahuja, G. (2000). Collaboration networks, structural holes, and innovation: A longitudinal study. Administrative Science Quarterly, 45(3), 425-455

Aldrich, H, Rosen, B, Woodward, W. (1987). The impact of social networks on business foundings and profit: A longitudinal study. Frontiers of Entrepreneurship Research, 7, 154-168.

Azen, R, \& Budescu, DV. (2003). The dominance analysis approach for comparing predictors in multiple regression. Psychological Methods, 8(2), 129.

Barney, J. (1991). Firm resources and sustained competitive advantage. Journal of Management, 17(1), 99-120

Bhide, A. (2000). The origin and evolution of new businesses. Oxford University Press. Oxford, UK.

Blau, PM (1977). Inequality and heterogeneity: A primitive theory of social structure (Vol. 7). New York: Free Press.

Bleeke, J, \& Ernst, D (Eds.) (1993). Collaborating to compete: Using strategic alliances and acquisitions in the global marketplace. New York: Wiley.

Brush, CG, \& Vanderwerf, PA. (1992). A comparison of methods and sources for obtaining estimates of new venture performance. Journal of Business Venturing, 7(2), 157-170.

Burt, R. S. (1992). Structural hole. Harvard Business School Press, Cambridge, MA.

Butler, JE, Brown, B, Chamornmarn, W. (2003). Informational networks, entrepreneurial action and performance. Asia Pacific Journal of Management, 20(2), 151-174.

Calantone, RJ, \& Schatzel, KE. (2000). Strategic foretelling: Communication-based antecedents of a firm's propensity to preannounce. Journal of Marketing, 64(1), 17-30.

Cannon, JP, \& Homburg, C. (2001). Buyer-supplier relationships and customer firm costs. Journal of Marketing, 65(1), 29-43.

Carlisle, E, \& Flynn, D. (2005). Small business survival in China: Guanxi, legitimacy, and social capital. Journal of Developmental Entrepreneurship, 10(01), 79-96.

Churchill, N. C., Carsrud, A. L., Gaglio, C. M., \& Olm, K. W. (1987). Entrepreneurs- Mentors, Networks, and Successful New Venture Development: An Exploratory Study. American Journal of Small Business, 12(2), 13-18.

Chen, X, \& Chen, CC. (2004). On the intricacies of the Chinese guanxi: A process model of quanxi development. Asia Pacific Journal of Management, 21, 305-324.

Coviello, NE, \& Munro, HJ. (1995). Growing the entrepreneurial firm: Networking for international market development. European Journal of Marketing, 29(7), 49-61.

Creswell, JW (2013). Research design: Qualitative, quantitative, and mixed methods approaches. Thousand Oaks: Sage publications. Creswell, J. W., \& Clark, V. L. P. (2011). Designing and conducting mixed methods research (2nd ed.). Thousand Oaks, CA: Sage.

Crosby, LA, Evans, KR, Cowles, D. (1990). Relationship quality in services selling: An interpersonal influence perspective. The Journal of Marketing, 54, 68-81.

De Vellis, RF, \& Dancer, LS. (1991). Scale development: Theory and applications. Journal of Educational Measurement, $31(1), 79-82$.

Dong, F. Y. (2000). Super speed mode: The main mode of 21st century enterprises. Boulder: Enterprise management press. Duncan, T, \& Moriarty, SE. (1998). A communication-based marketing model for managing relationships. The Journal of Marketing, 62(2), 1-13.

Dwyer, FR, Schurr, PH, Oh, S. (1987). Developing buyer-seller relationships. The Journal of Marketing, 51, 11-27.

Farace, R. M., Monge, P. R. P., \& Russell, H. 1977. Communicating and organizing. Reading, MA: Addison-Wesley. Field, A. (2009). Discovering statistics using SPSS. Sage publications. New York City, NY.

Forza, C, \& Vinelli, A. (1997). Quick response in the textile-apparel industry and the support of information technologies. Integrated Manufacturing Systems, 8(3), 125-136.

Frazier, GL. (1983). Interorganizational exchange behavior in marketing channels: A broadened perspective. The Journal of Marketing, 47(4), 68-78.

Ganesan, S. (1994). Determinants of long-term orientation in buyer-seller relationships. Journal of Marketing, 58(2), 1-19.

Garson, G. D. (2008). Path analysis. From Statnotes: Topics in multivariate analysis. Retrieved, 9(05), 1-16. 
Granovetter, M. (2005). The impact of social structure on economic outcomes. The Journal of Economic Perspectives, 19(1), 33-50,

Gu, Q. (2002). SMEs and Chinese apparel industry development. Journal of Zhejiang Textile \& Fashion College, 1, 23-25. Gulati, R, Nohria, N, Zaheer, A. (2000). Guest editors' introduction to the special issue: Strategic networks. Strategic Management Journal, 21(3), 199-201.

Hannan, MT, \& Freeman, J. (1984). Structural inertia and organizational change. American Sociological Review, 49(2), 149-164 Hansen, EL. (1995). Entrepreneurial networks and new organization growth. Entrepreneurship Theory and Practice, 19(4), 7-20. $\mathrm{He}, \mathrm{M}$. (2015). Data showed that eight companies were born per minute in China with the start-up failure rate of $80 \%$. Retrieved from: http://www.chinanews.com/cj/2015/12-06/7657906.shtml

Hite, J. M. (1999). Embedded network ties in emerging entrepreneurial firms: Patterns, processes and paths. Salt Lake City, UT: University of Utah.

Hooper, D., Coughlan, J., \& Mullen, M. (2008). Structural equation modelling: Guidelines for determining model fit. Articles, 2 . Hunt, S. D. (2002). Foundations of marketing theory: Toward a general theory of marketing. Armonk, NY: ME Sharpe. Kirzner, Israel M. (1973). Competition and Entrepreneurship. Chicago, IL: University of Chicago Press.

Kumar, N, Stern, LW, Achrol, RS. (1992). Assessing reseller performance from the perspective of the supplier. Journal of Marketing Research, 29(2), 238.

Lages, C, Lages, CR, Lages, LF. (2005). The RELQUAL scale: A measure of relationship quality in export market ventures Journal of Business Research, 58(8), 1040-1048.

Larson, A, \& Starr, JA. (1993). A network model of organization formation. Entrepreneurship Theory and Practice, 17, 5-5.

Lee, DY, \& Dawes, PL. (2005). Guanxi, trust, and long-term orientation in Chinese business markets. Journal of International Marketing, 13(2), 28-56.

$\mathrm{Li}, \mathrm{H}$, \& Zhang, Y. (2007). The role of managers' political networking and functional experience in new venture performance: Evidence from China's transition economy. Strategic Management Journal, 28(8), 791-804.

Li, Y. (2014). The analysis of Chinese apparel brand development. Tianjin Textile Technology, 1, 6-7.

Liu, R, \& Yao, Z. (2005). Review of the quality of relationship research. Foreign Economies \& Management, 27(1), 27-33.

Luo, Y, \& Chen, M. (1997). Does guanxi influence firm performance? Asia Pacific Journal of Management, 14, 1-16.

Meng, X. Y. (2013). Research on the relationship among leadership behavior of entrepreneurs, organizational learning capability and competitive advantage of new venture. Retrieved from CNKI Dissertations

Menon, A, Bharadwaj, SG, Adidam, PT, Edison, SW. (1999). Antecedents and consequences of marketing strategy making: A model and a test. The Journal of Marketing, 63(2), 18-40.

Menon, A, Bharadwaj, SG, Howell, R. (1996). The quality and effectiveness of marketing strategy: Effects of functional and dysfunctional conflict in intraorganizational relationships. Journal of the Academy of Marketing Science, 24(4), 299-313.

Meyers, LS, Gamst, G, Guarino, AJ (2006). Applied multivariate research: Design and interpretation. Thousand Oaks, Sage.

Mohr, J, \& Nevin, JR. (1990). Communication strategies in marketing channels: A theoretical perspective. The Journal of Marketing, 54(4), 36-51.

Naudé, P, \& Buttle, F. (2000). Assessing relationship quality. Industrial Marketing Management, 29(4), 351-361.

Ngoma, TR. (2016). It is not whom you know, it is how well you know them: Foreign entrepreneurs building close guanxi relationships. Journal of International Entrepreneurship, 14(2), 239-258.

Nohria, N. (1992). Introduction: Is a network perspective a useful way of studying organizations. in N. Nohria and R.G. Eccles (eds), Networks and organizations: Structure, form, and action. Boston, MA: Harvard Business School Press. 1, 22.

Obstfeld, D. (2005). Social networks, the tertius iungens orientation, and involvement in innovation. Administrative Science Quarterly, 50(1), 100-130.

Peng, MW. (2003). Institutional transitions and strategic choices. Academy of Management Review, 28(2), 275-296.

Reagans, R, \& McEvily, B. (2003). Network structure and knowledge transfer: The effects of cohesion and range. Administrative Science Quarterly, 48(2), 240-267.

Roberts, K, Varki, S, Brodie, R. (2003). Measuring the quality of relationships in consumer services: An empirical study. European Journal of Marketing, 37(1/2), 169-196.

Salancik, GR, \& Pfeffer, J. (1978). Who gets power-And how they hold on to it: A strategic-contingency model of power. Organizational Dynamics, 5(3), 3-21.

Shin, SK, Ishman, M, Sanders, GL. (2007). An empirical investigation of socio-cultural factors of information sharing in China. Information Management, 44(2), 165-174.

Shirokova, G, \& Shatalov, A. (2010). Factors of new venture performance in Russia. Management Research Review, 33(5), 484-498,

Su, D, Du, Q, Sohn, D, Xu, L. (2017). Can high-tech ventures benefit from government Guanxi and business Guanxi? The moderating effects of environmental turbulence. Sustainability, 9(1), 142.

Teddlie, C., \& Tashakkori, A. (2009). Foundations of mixed methods research. Thousand Oaks, CA: Sage.

Walter, A, Müller, TA, Helfert, G, Ritter, T. (2003). Functions of industrial supplier relationships and their impact on relationship quality. Industrial Marketing Management, 32(2), 159-169.

Wonglimpiyarat, J. (2007). Management and governance of venture capital: A challenge for commercial banks. Technovation, 27(12), 721-731.

Wright, S. (1934). The method of path coefficients. The annals of mathematical statistics, 5(3), 161-215.

Xia, Y, Qiu, Y, Zafar, AU. (2007). The impact of firm resources on subsidiary's competitiveness in emerging markets: An empirical study of Singaporean SMEs' performance in China. Multinational Business Review, 15(2), $13-40$.

Yang, F. (2011). The importance of guanxi to multinational companies in China. Asian Social Science, 7(7), 163.

Yen, DA, Barnes, BR, Wang, CL. (2011). The measurement of guanxi: Introducing the GRX scale. Industrial Marketing Management, 40(1), 97-108.

Yu, H. J. (2007). The research on the quality of external network relationships, internal capabilities, and new venture growth performance. Retrieved from CNKI Dissertations.

Yu, S. Z. (2012). The effect of entrepreneurial resource and entrepreneurial strategy on entrepreneurial performance-Based on moderating mechanism of environment and organization structure. Master's thesis. Beijing: Zhejiang University. Retrieved from CNKI Database. 
Yum, JO. (1988). The impact of Confucianism on interpersonal relationships and communication patterns in East Asia. Communication Monographs, 55(4), 374-388.

Zhao, L, \& Aram, JD. (1995). Networking and growth of young technology-intensive ventures in China. Journal of Business Venturing, 10(5), 349-370.

Zhuang, G, Xi, Y, Tsang, AS. (2010). Power, conflict, and cooperation: The impact of guanxi in Chinese marketing channels. Industrial Marketing Management, 39(1), 137-149.

Zou, F, \& Gao, Y. (2007). Guanxi with government as a source of competitive advantage in mainland China. Journal of American Academy of Business, 10(2), 158-162.

Zou, H, Chen, X, Ghauri, P. (2010). Antecedents and consequences of new venture growth strategy: An empirical study in China. Asia Pacific Journal of Management, 27(3), 393-421.

Submit your manuscript to a SpringerOpen ${ }^{\circ}$ journal and benefit from:

- Convenient online submission

- Rigorous peer review

- Open access: articles freely available online

- High visibility within the field

- Retaining the copyright to your article

Submit your next manuscript at $>$ springeropen.com 